\title{
Tobacco control and sustainable development: shared challenges and future opportunities
}

\author{
Britta K. Matthes ${ }^{1}$, Mateusz Zatoński ${ }^{1,2,3}$ \\ 'Tobacco Control Research Group, Department for Health, University of Bath, UK \\ ${ }^{2}$ Health Promotion Foundation, Nadarzyn, Poland \\ ${ }^{3}$ European Observatory of Health Inequalities, the President Stanisław Wojciechowski State University of Applied Sciences \\ in Kalisz, Poland
}

A previous version of this article was published on the University of Bath Centre for Development Studies blog on World No Tobacco Day, 31 May 2019.?

\begin{abstract}
In recent years, scholars and public health officials have increasingly perceived tobacco as a threat to sustainable development. This article explores how stronger tobacco control efforts can contribute to the achievement of the Sustainable Development Goals (SDGs) set by the United Nations General Assembly in 2015. Most obviously, given that tobacco use and exposure account for over 7.2 million deaths annually, tobacco control is a fundamental prerequisite for achieving SDG 3: Good Health and WellBeing. However, the article also shows how tobacco is, among others, a driver of poverty and inequalities, a threat to sustainable economic growth, a challenge to the environment, and an obstacle to good governance. In effect, tobacco hinders progress on a host of other SDGs. Particular emphasis is placed on SDG 17: Partnership for the goals. While tobacco control partnerships for the past decades have helped attain public health progress globally, there is a risk of this SDG being hijacked by the tobacco industry and other corporate actors, who use it as a tool to justify the proliferation of public-private partnerships. Finally, the article calls for greater cross-disciplinary thinking and closer collaboration between tobacco control and development scholars, which could be crucial in designing successful tobacco control interventions in low- and middle-income countries, and could help achieve the Sustainable Development Agenda.
\end{abstract}

KEY WORDS: sustainable development, tobacco control, TTCs, LMICs, public-private partnership.

ADDRESS FOR CORRESPONDENCE: Britta K. Matthes, Department for Health, University of Bath, UK,

e-mail: b.matthes@bath.ac.uk

\section{INTRODUCTION - TOBACCO CONTROL AS A DEVELOPMENT PRIORITY}

In May 2017, just months before the end of her second term as Director-General of the World Health Organization (WHO), Margaret Chan spoke about championing the WHO's mission to fight tobacco use as one of her proudest achievements in office. What was surprising was the justification that followed. Dr. Chan did not focus on the usual costs associated with smoking - the millions of premature deaths globally, the US\$ 1.4 trillion wasted annually in healthcare expenditure and lost productivity, or the human suffering brought by the host of cancers, heart diseases, and respiratory diseases caused by tobacco use. Instead, she declared that 'tobacco is a deadly threat to global development', affecting 'every country on every level and across many

${ }^{1}$ Matthes BK, Zatonski M. Addressing the tobacco epidemic as a sustainable development priority: the need for cross-disciplinary thinking. CDS Blog. http://blogs.bath.ac.uk/cds/2019/05/31/addressing-the-tobacco-epidemic-as-a-sustainable-development-priority-the-need-forcross-disciplinary-thinking/, accessed on 10.07.2019. 
sectors - economic growth, health, education, poverty, and the environment' [1]. The slogan 'Tobacco - a threat to development' became the theme of the 2017 World No Tobacco Day.

This was not the first time that tobacco has been recognised by the public health community as posing a threat 'to the cause of social and environmental justice, rather than just being a matter of individual health [2]. In 2015, the magnitude of the tobacco epidemic was acknowledged in the 2030 Agenda for Sustainable Development [3]. The agenda, which encompasses 17 Sustainable Development Goals (SDGs), directly addresses the importance of tobacco control in SDG Target 3.a, calling for the strengthening of 'the implementation of the World Health Organization Framework Convention on Tobacco Control [WHO FCTC] in all countries'.

The FCTC, adopted in 2003, was the first legally binding multilateral international public health treaty. It covers the production, sale, distribution, advertisement, and taxation of tobacco, setting an evidence-based framework of minimum requirements for the signatory states in controlling tobacco products [4]. The FCTC - as of May 2019 - was legally binding in 181 ratifying countries. While in most high-income countries (HICs) the implementation of the FCTC has advanced markedly, in some low- and middle-income countries (LMICs) the progress has been much slower $[5,6]$. This is particularly alarming given that in 2018 four out of five smokers (or 880 million out of 1.1 billion smokers) lived in LMICs [7].

Drawing on evidence and examples from LMICs, in this article we explore key synergies between the SDGs and tobacco control. We demonstrate that strengthening tobacco control is not only relevant for achieving SDG 3 (Good Health and Well-Being), but also for broader social, economic, and environmental dimensions of sustainable development encompassed in several other SDGs [8]. We also point to the agenda of the transnational tobacco companies (TTCs) as a fundamental obstacle to achieving the SDGs and, more widely, to continued public health progress. To conclude, we argue that in order to drive progress in sustainable development, especially given the interference of TTCs, international tobacco control networks need to be further strengthened in LMICs. These processes need to be accompanied by greater cross-disciplinary collaboration, especially between the fields of tobacco control and development studies.

\section{TOBACCO AS A LEADING CAUSE OF POOR} HEALTH - SDG 3: GOOD HEALTH AND WELL-BEING

Apart from calling for the global implementation of the FCTC, another key target of SDG 3 is 'reducing premature deaths from noncommunicable diseases [NCDs] by one-third by 2030' (Target 3.4). Tobacco use and exposure to second-hand smoke are leading risks of NCDs, responsible for a huge toll in morbidity, and accounting for over 7.2 million deaths annually [7]. This figure is projected to rise markedly, with the WHO [9] estimating a billion tobacco-related deaths in the $21^{\text {st }}$ century if current smoking rates persist.

Tobacco use is not only associated with NCDs but also with a higher risk of infections such as tuberculosis and AIDS [10], which are more prevalent in LMICs than in HICs. By weakening the immune system, tobacco use facilitates the contraction of such diseases. Effective tobacco control is therefore also a key intervention in achieving the SDG target 3.3 'to end epidemics of (...) communicable diseases'.

\section{TOBACCO AS A DRIVER OF POVERTY AND INEQUALITIES - SDG 1: NO POVERTY, AND SDG 10: REDUCED INEQUALITIES}

Tobacco use tends to be highest among the poor and other vulnerable groups. In a study of 48 LMICs, the poorest males were 2.5-times more likely to be smokers than their richest counterparts [11]. Tobacco use has been found to exacerbate poverty and contribute to health and other inequalities within and between countries. When one or more members of a household are tobacco consumers, more than 10 per cent of total household income is often spent on tobacco - money which could otherwise be used for necessities such as food, education, or health care [1]. Smokers are also more likely to experience food insecurity [12].

Economists have pointed out that the global 'economic burden of tobacco use is enormous and is increasingly borne by LMICs' [13]. In recent years, the increase in the number of smokers has been largely confined to countries with widespread poverty, particularly in Sub-Saharan Africa (SSA) [14]. Between 1990 and 2012, the demand for cigarettes increased by 44 per cent in 22 African countries, which was accompanied by a 106 per cent increase in cigarette production [15]. It is estimated that by 2030 , over 80 per cent of tobacco-related deaths will occur in LMICs [13].

In SSA, the first worrying signs are already there the smoking prevalence among boys, at 9\%, in 2013 was higher than among their peers in LMICs in other WHO regions, including the Eastern Mediterranean, SouthEast Asia, and Western Pacific [16]. Smoking rates are predicted to increase in 18 African countries by 2025 [17]. The number of smokers in the African region, estimated at 77 million, is projected to rise by nearly $40 \%$ from 2010 levels by 2030 [18]. The resulting epidemic of tobacco-related diseases will hit the world's poorest continent with full force, and further exacerbate global health inequalities, if those trends are not reversed.

The activity of the TTCs has been a key driver behind some of these worrying trends. Big tobacco companies have been investing heavily in LMICs, and in particular in SSA. In countries with high poverty rates TTCs often attempt to capture the market by offering very cheap cigarettes and by selling single sticks, which are 
more affordable for the poor and young people [19]. In markets with lower smoking rates, TTCs target vulnerable groups with aggressive marketing efforts in order to enhance tobacco consumption $[20,21]$.

The TTCs have also become entrenched in LMICs as powerful economic actors carrying significant policy clout, becoming an ever more powerful opponent to tobacco control efforts. In some countries this was achieved through consolidating a long-established presence. For example, British American Tobacco (BAT) tends to enjoy near-monopoly in countries with a history of British colonialism, including Africa's powerhouses: South Africa and Nigeria. In the latter, BAT built a state-of-the-art manufacturing plant in 2003 to service West African countries, and in 2016 opened its West Africa Head Office in Lagos [22]. Other countries, especially those that still have state-owned tobacco monopolies, are still 'up for grabs'. Between 2016 and 2017 Japan Tobacco International spent almost a billion dollars to buy a majority share of Ethiopia's National Tobacco Enterprise [23]. Research conducted in Eastern Europe after the collapse of the Soviet Union has shown that the replacement of inefficient, backward, state-owned behemoths with competitive, modern, marketing-savvy TTCs is not good news for public health and can lead to weaker tobacco control and rising smoking rates [24].

\section{FACING A SMOKING EPIDEMIC AMONG WOMEN - SDG 5: GENDER EQUALITY}

Historically, smoking has been far more common among men than among women [25]. However, in recent decades we have seen this gap slowly eroding, with 27 per cent of all countries recording significant decreases in male daily smoking, versus only 16 per cent recording reductions for women. While this shift has been most pronounced in HICs, in some LMICs, including Russia and Indonesia, female daily smoking has significantly increased since 1990 [26].

In many LMICs the epidemiological picture is less clear because systems of public health surveillance are less developed, making it necessary to rely on modelling. Nonetheless, there is evidence suggesting that in certain low-income contexts, in particular in SSA, smoking rates among girls are significantly higher than among adult women [16]. With Africa's demographic 'youth bulge', those trends could spell a public health catastrophe in the making.

Evidence shows how the TTCs use a variety of tactics to encourage and normalise tobacco use among youths and women in LMICs. These include offering free samples and sponsoring events for youth as well as deploying 'trend setters' to promote smoking among girls and women [27]. In settings with low social acceptability of female smoking, i.e. in parts of Africa, Eastern Europe, and South-East Asia, tobacco companies pursued culturally attuned marketing campaigns to draw women to smoking [28].

\section{TOBACCO'S FALSE PROMISES OF SUSTAINABLE GROWTH - SDG 8: DECENT WORK AND ECONOMIC GROWTH, AND SDG 12: RESPONSIBLE CONSUMPTION AND PRODUCTION}

The TTCs have attempted to portray their business as a driver of economic growth and job creation in LMICs. In some of the world's poorest countries they have forcefully pushed for the development of tobacco farming, presenting it as an economic and development opportunity [29]. Millions of farmers have been convinced to focus on tobacco cultivation, becoming reliant on tobacco industry custom [29] and contracts that often do not guarantee farmers a minimum price [30]. Instead of lifting farmers out of poverty, tobacco cultivation has been found to often lead farmers to accrue loans that they are unable to repay $[30,31]$ and to rely on government subsidies [29], while large buyers control supply chains [32].

The tobacco economy has also been at odds with fostering responsible production, distribution, and consumption mechanisms. On production, tobacco farming exposes the world's 33 million tobacco farm workers, over 50 per cent of whom are women and minors, to a host of dangerous chemicals $[29,33,34]$. One common condition, green tobacco sickness, with an estimated prevalence of between 8.2 and 47 per cent among tobacco growers globally, is particularly common among Asian and South American tobacco harvesters [35]. This is incompatible with the ideas of decent work and responsible production.

The TTCs have historically engaged in problematic practices regarding their products are distributed to their end customers. Overwhelming evidence exists pointing to the involvement of the tobacco industry in global cigarette smuggling throughout the 1990s [27, 36, 37]. While in recent years the TTCs have claimed they are now victims of tobacco smuggling, they continue to overproduce and oversupply tobacco products in some markets, with the knowledge that the excess will end up on the illicit market [38]. Evidence from government investigations, whistle-blowers, and leaked tobacco industry documents, also in LMICs, indicate that TTCs are still involved in smuggling and use distributors with a known history of smuggling [39, 40].

Finally, the notion of responsible consumption is difficult to apply in the discussion of a product, which, if used as intended by its producer, will kill up to half of all its users [41]. Responsible production and consumption also need to take into consideration their broader environmental consequences, which are covered by SDGs 14 and 15 .

\section{TOBACCO AS AN ENVIRONMENTAL CHALLENGE - SDG 14: LIFE BELOW WATER, AND SDG 15: LIFE ON LAND}

At all stages of their life cycle, tobacco products pose a serious threat to the environment [42]. One example are 
the billions of cigarette butts discarded every day, which constitute one of the world's leading environmental pollutants. They are the top item collected in coastal cleanups, with cigarette filters constituting a major source of plastic waste in the oceans [43]. The toxic chemicals that can leach from cigarette butts can be highly dangerous to maritime life - in laboratory studies a single smoked cigarette butt dropped in one litre of water is sufficient to kill marine and freshwater fish species [44]. Studies also found increased water pollution around tobacco farming communities [45]. However, more research is needed to fully understand the effects of cigarette waste on our oceans, rivers, and lakes, given the growing scale of the phenomenon.

On land, tobacco growing and manufacturing have been found to contribute to agrochemical pollution, soil degradation, and deforestation [45]. The WHO [46] reports that every year around 200,000 hectares of forest and woodland are cut down due to tobacco farming. Tobacco manufacturing also produces a large amount of waste. In 1995, an estimated 2.3 billion kilograms of manufacturing waste and 209 million kilograms of chemical waste were produced by the global tobacco industry [46]. The negative effects of tobacco on smokers' health is well known, but it is also increasingly clear that even brief exposure to second-hand smoke can be harmful to the health of those surrounding the smoker - not only adults and children, but also pets. Also of concern are the effects of swallowing cigarettes on children, pets, and wild animals, which are still under-researched $[47,48]$.

\section{TOBACCO AS AN OBSTACLE TO GOOD GOVERNANCE - SDG 16: PEACE, JUSTICE AND STRONG INSTITUTION}

The FCTC provides a systematic roadmap to minimise, and eventually overcome, the detrimental impact that tobacco production, distribution, and consumption have on the ability to meet the SDGs across the globe. Amongst others, the FCTC includes a measure designed to help curtain the influence of the TTCs on the policy process. FCTC Article 5.3 obliges the treaty signatories to the following: "In setting and implementing their public health policies with respect to tobacco control, Parties shall act to protect these policies from commercial and other vested interests of the tobacco industry in accordance with national law".

However, the adoption of the measures of the FCTC, and the enforcement of Article 5.3, have not been even. While HICs have on average translated around two thirds of FCTC provisions into their legal and regulatory frameworks, in LMICs the figure has been under $50 \%$ [5]. Given the overproportionate toll of tobacco on poorer countries, why has the progress in adopting the FCTC been slower in LMICs? Part of the answer must be sought in the influence of the five tobacco companies that collectively control almost $90 \%$ of the world's cigarette market [32].

In recent decades, faced with stagnating or declining smoking rates in their traditional high-income markets, and with well-organised public health networks using the FCTC to exercise pressure on policy-makers and governments for stricter regulation, the tobacco industry has turned its gaze towards LMICs as their main target for expansion and source of future growth [49]. Research has revealed the myriad ways in which cigarette companies oppose tobacco control regulation [27, 50-52]. These include denying the health risks of smoking [53], manufacturing doubt about the effectiveness of public health legislation [54], undermining sound science, and funding influential front and lobbying groups [55]. One measure attempting to systematically gauge tobacco industry influence, the Tobacco Industry Interference Index, has shown that in Southeast Asian countries the TTCs continue to interfere with government efforts to strengthen public health provisions by lobbying and deterring policymakers from implementing effective tobacco control policies [56].

When governments of smaller LMICs have sought to introduce evidence-based tobacco control policies, for example on plain packaging, the TTCs have threatened them with lawsuits and international tribunals in numerous cases $[17,27]$. With their vast resources, influence, and an agenda that stands in direct conflict with development priorities, the tobacco industry continues to be a threat to building good governance, as well as transparent, accountable, effective institutions in LMICs.

\section{TOBACCO INDUSTRY ATTEMPTS TO HIJACK THE SUSTAINABLE DEVELOPMENT AGENDA - SDG 17: PARTNERSHIP FOR THE GOALS}

The SDG 17 aims to strengthen global partnerships in support of the Sustainable Development Agenda. In recent decades, such partnerships have become a driver of tobacco control progress and given rise to an increasingly cohesive international epistemic tobacco control community [57]. The ability of local health advocates to tap into such international tobacco control networks, along with a good understanding of the local context, seem to have underpinned the ability to implement stringent tobacco control provisions in LMICs [58-62].

However, in recent years SDG 17 has also become the centrepiece of the strategy of the tobacco industry to portray itself as an ally in the efforts towards sustainable development. Research suggests that the TTCs have increasingly adopted the development rhetoric, seeing SDG 17 as a tool that could help justify the proliferation of public-private partnerships [63]. Such forms of engagement of public bodies with the industry (including tobacco, alcohol, and food companies) have often been found to be ineffective in achieving public health 
goals and have been used by business interests to block or weaken regulation and ultimately resist change [64, $65]$. At the same time, they provide an avenue for the TTCs to normalise their involvement in policy debates. In the words of BAT's Chief Executive Officer Nicandro Durante, 'Goal 17, with its focus on partnerships, is also particularly relevant. Working collaboratively as part of multi-stakeholder partnerships has always been central to our approach to sustainability' [63].

Under the guise of a commitment to the Sustainable Development Agenda the TTCs attempt to depict themselves as part of the solution rather than the problem, referencing their corporate social responsibility activities, the strength of their supply chains, which can allegedly benefit farmers in LMICs, as well as their widely publicised efforts to reduce environmental degradation [66-69]. Throughout, they present the SDGs as their rationale for engaging with actors and organisations at regional, national, and global levels [70]. Recent examples include the Philip Morris-funded Foundation for a Smoke-Free World (attempting to establish research collaborations with academics and governmental agencies), as well as the tobacco industry's active presence on the fora of international organisations, including the International Labour Organisation or the World Trade Organisation [71-73].

In order for the tobacco control community to effectively counter the TTCs' misleading use of sustainable development rhetoric, coordinated global systems of monitoring and sharing of best practice need to be developed. These can help underpin responses to the multi-faceted activity of the TTCs. Existing networks should be used in particular to strengthen tobacco control in LMICs, through capacity building, deepening international collaborations, and fostering local leaders and enabling them to draw on the vast pool of experiences and case studies from around the world [74-77]. Global tobacco control networks also need to be sustainable, because adopting legislative measures is only the first step, with their implementation and enforcement being equally important.

\section{THE NEED FOR CROSS-DISCIPLINARY THINKING AND A CALL FOR FURTHER RESEARCH}

Thus far, the bulk of tobacco control research, and in particular research on tobacco industry interference, has focused on high-income settings. While this has begun to change in recent years $[27,74,75,78]$, we still know relatively little about the needs of local tobacco control advocates in LMICs and how they can be best supported by global networks in countering the interference of the tobacco industry. With LMICs now at the core of the TTCs' business expansion plans, understanding and addressing these needs is now more urgent than ever.
Tobacco Control Research at the University of Bath: Together with international partners, the Tobacco Control Research Group within the Department for Health has been awarded major funding from Bloomberg Philanthropies to lead a new global tobacco industry watchdog called STOP (Stopping Tobacco Organizations and Products). The project runs until late 2021. Visit the project website at https://exposetobacco.org/

On 19 July 2019, Gan Quan, a Partner in STOP, co-signed an open letter to the Secretary General of the United Nations, António Guterres, regarding the role of the tobacco industry in the 2030 Agenda for Sustainable Development. See https://www.fctc.org/joint-letter-to -the-un-sg-re-the-role-of-the-tobacco-industry-in-the2030-agenda-for-sustainable-development/.

Addressing this gap in knowledge is also important for another reason. When opposing tobacco control regulation, the TTCs seem to be taking an approach that combines their assets of a global reach and of local expertise. On one hand, they seem to be using similar tactics globally in trying to secure preferred policy outcomes, both in terms of the economic, social, and political arguments they use, and in terms of coalitions they try to build to amplify their voice $[27,78]$. On the other hand, in-depth case studies of LMICs have revealed the industry's ability to tailor these overarching global strategies to exploit local specificities in LMICs [22, 37, 79-81]. Research on the political influence of the tobacco industry should therefore also incorporate both these dimensions: first, the global picture, mapping out cross-cutting similarities in industry tactics, as well as inter- and transnational efforts to prevent and counter industry interference; and second, the contextual specificities of LMICs, of regions and individual countries, which need to be taken into consideration when developing interventions mitigating industry activity.

To obtain a sound understanding of the local perspective, in particular, a more tight-knit collaboration needs to be established between tobacco control researchers and development study scholars and practitioners. Development experts can provide insights on topics like corporate social responsibility and local livelihoods, informal economies, civil society, governance, and corruption, as well as an in-depth and intimate knowledge of local contexts. These can be crucial in informing research agendas facilitating the development of effective strategies to oppose corporate actors seeking to undermine effective public health policies in LMICs. Similarly, the debates on global supply chains, another topic often studied under the banner of development studies, can help public health scholars make sense of the bigger picture of the tobacco epidemic.

Some of the broad, scoping research questions that need to be asked in order to assess the potential path- 
ways of future cross-disciplinary work between the tobacco control and development studies fields are:

- To what extent is there an overlap between tobacco control and development scholarship?

- What are the gaps in tobacco control and development scholarship that need to be filled to better address the smoking epidemic in LMICs?

- To what extent does development scholarship acknowledge tobacco control as an important element of sustainable development?

- To what extent does tobacco control scholarship consider sustainable development as a priority in countering TTC influence?

- What are the tensions between tobacco control priorities and the sustainable development agenda (e.g. in relation to tobacco farming), and how can they be overcome?

- How do tobacco control experts see and make sense of sustainable development, and how do development experts see and make sense of tobacco control?

- What are the relations between TTCs and the international organisations that are leading the development and implementation of the sustainable development agenda?

\section{CONCLUSIONS}

Despite significant progress in tobacco control in some regions of the world, the smoking epidemic is still on the rise in several LMICs, and attempts to arrest it are undermined by the activity of TTCs. In this article we show how closely tobacco control priorities are aligned with the Sustainable Development Agenda, and how conversely - tobacco production and consumption is highly inconsistent with the SDGs, despite TTCs' claims otherwise (see, for example, BAT, 2018, Imperial Brands, 2018, JTI, 2018, PMI, 2018). Effective interventions that could help lower smoking prevalence and initiation would not only directly contribute to achieving SDG 3 (Good Health and Well-Being), but also contribute to the efforts linked to ending poverty (SDG 1), ending inequality (SDG 10), strengthening gender equality (SDG 5), facilitating decent work (SDG 8), promoting responsible production and consumption (SDG 12), and protecting life below water and on land (SDGs 14 and 15). Strong institutions, covered by SDG 16, are vital for advancing tobacco control and countering the political activities of TTCs.

Finally, the development of strong partnerships (SDG 17) in tobacco control requires, on one hand, the strengthening of international networks between health advocates, researchers, and organisations in HICs and LMICs and, on the other, more in-depth research on LMICs, which would yield a better understanding of the similarities, differences, and specificities of tobacco politics in these countries. In achieving the latter, tobacco control researchers should be encouraged to collaborate across disciplinary boundaries, and in particular to learn from, and develop collaborations with, development scholars working on LMICs.

\section{DISCLOSURE}

All authors are part of the global tobacco industry watchdog STOP (Stopping Tobacco Organizations and Products), which is funded by Bloomberg Philanthropies. The authors report no conflict of interest.

\section{References}

1. Chan M. Tobacco is a deadly threat to global development, 2017. Available from: https://www.who.int/news-room/commentaries/detail/tobacco-is-a-deadly-threat-to-global-development (accessed: 25 April 2019).

2. Malone RE, Yang JS. Tobacco: a threat to development? Tob Control 2017; 26: 241-242.

3. UN 2015. Transforming Our World: The 2030 Agenda for Sustainable Development. A/RES/70/1. Available from: https:// www.un.org/en/development/desa/population/migration/ generalassembly/docs/globalcompact/A_RES_70_1_E.pdf (accessed: 05 May 2019).

4. WHO. WHO Framework Convention on Tobacco Control, 2003. Available from: https://www.who.int/tobacco/framework/WHO_FCTC_english.pdf, (accessed: 23 April 2019).

5. WHO. WHO Report on the Global Tobacco Epidemic 2017: Monitoring tobacco use and prevention policies. Available from: https://apps.who.int/iris/bitstream/hand le/10665/255874/9789241512824-eng.pdf; jsessionid=BC9F4A66400BA994D9FD21E5E1118204? sequence $=1$ (accessed: 29 April 2019).

6. Anderson CL, Becher H, Winkler V. Tobacco control progress in low and middle income countries in comparison to high income countries. Int J Environ Res Public Health 2016; 13: pii: E1039.

7. WHO. Fact sheet: Noncommunicable diseases, 2018a. Available from: https://www.who.int/news-room/fact-sheets/detail/ noncommunicable-diseases (accessed: 11 May 2019).

8. WHO. n.d.-a. Tobacco Control \& The Sustainable Development Goals. Available from: http://www.euro. who.int/_data/assets/pdf_file/0020/340193/TOBACCO-CONTROL-AND-THE-SUSTAINABLE-DEVELOPMENT-GOALS_Edited.pdf?ua=1)\%20.\%20\%20 (accessed: 05 May 2019).

9. WHO. WHO Report on the Global Tobacco Epidemic 2008: The MPOWER package. Available from: https:/www.who.int/ tobacco/mpower/gtcr_download/en/ (accessed: 02 May 2019).

10. McNeish H. Rocketing smoking rates across Africa stoke TB and HIV fears. BMJ 2018; 361: k1884.

11. Hosseinpoor AR, Parker LA, Tursan d'Espaignet E, Chatterji S. Socioeconomic inequality in smoking in low-income and middle-income countries: results from the World Health Survey. PLoS One 2012; 7: e42843.

12. Kim JE, Tsoh JY. Cigarette smoking among socioeconomically disadvantaged young adults in association with food insecurity and other factors. Prev Chronic Dis 2016; 13: E08. 
13. NCI-WHO. Monograph 21: The Economics of Tobacco and Tobacco Control, 2016. Available from: https://cancercontrol. cancer.gov/brp/tcrb/monographs/21/docs/m21_complete.pdf (accessed: 10 May 2019).

14. World Bank. 2017. The State of the Poor: Where are the Poor and where are they Poorest? Available from: https://www. worldbank.org/content/dam/Worldbank/document/State_of_ the_poor_paper_April17.pdf (accessed: 15 May 2019).

15. Vellios N, Ross H, Perucic AM. Trends in cigarette demand and supply in Africa. PLoS One 2018; 13: e0202467.

16. Blecher E, Ross H. Tobacco use in Africa: tobacco control through prevention. Available from: https://www.cancer.org/ content/dam/cancer-org/cancer-control/en/reports/tobacco-use-in-africa-tobacco-control-through=prevention.pdf (accessed: 03 May 2019).

17. Boseley S. Threats, bullying, lawsuits: tobacco industry's dirty war for the African market. Available from: https://www.theguardian.com/world/2017/jul/12/big-tobacco-dirty-war-africa-market (accessed: 08 May 2019).

18. Méndez D, Alshanqeety O, Warner KE. The potential impact of smoking control policies on future global smoking trends. Tob Control 2013; 22: 46-51.

19. ACTA. 2018. Fact sheet: The sale of single sticks of cigarettes in Africa. Available from: https://atca-africa.org/images/pdf/ Atca-single-sticks/ATCA-FACTSHEET-SALE-OF-SINGLESTICKS-IN-AFRICA.pdf (accessed: 15 May 2019).

20. Connolly GN, Behm I, Osaki Y, Wayne GF. The impact of menthol cigarettes on smoking initiation among non-smoking young females in Japan. Int J Environ Res Public Health 2011; 8: 1-14.

21. Lee K, Carpenter C, Challa C, et al. The strategic targeting of females by transnational tobacco companies in South Korea following trade liberalisation. Global Health 2009; 5: 2.

22. Egbe CO, Bialous SA, Glantz SA. Avoiding "a massive spin-off effect in West Africa and beyond": the tobacco industry stymies tobacco control in Nigeria. Nicotine Tob Res 2017; 19: 877-887.

23. Ashenafi H. 2017. Ethiopia: govt gives up tobacco monopoly for U.S.\$434 million. Available from: https://allafrica.com/stories/201801020375.html (accessed: 10 May 2019).

24. McKee M, Bobak M, Rose R, et al. Patterns of smoking in Russia. Tob Control 1998; 7: 22-26.

25. Brandt AM. The cigarette century: the rise, fall, and deadly persistence of the product that defined America. Basic Books, New York 2007.

26. Reitsma MB, Fullman N, Ng M, et al. Smoking prevalence and attributable disease burden in 195 countries and territories, 1990-2015: a systematic analysis from the Global Burden of Disease Study 2015. Lancet 2017; 389: 1885-1906.

27. Gilmore AB, Fooks G, Drope J, et al. Exposing and addressing tobacco industry conduct in low-income and middle-income countries. Lancet 2015; 385: 1029-1043.

28. Hitchman SC, Fong GT. Gender empowerment and femaleto-male smoking prevalence ratios. Bull World Health Organ 2011; 89: 195-202.

29. $\mathrm{Hu} \mathrm{TW}$, Lee AH. Commentary: Tobacco control and tobacco farming in African countries. J Public Health Policy 2015; 36: 41-51.
30. Goma F, Jeffrey D, Zulu R, et al. 2017 The Economics of Tobacco Farming in Zambia (revised version). Available from: https://www.cancer.org/content/dam/cancer-org/research/ economic-and-healthy-policy/economics-tobacco-farming-zambia-2017.pdf (accessed: 11 May 2019).

31. Agonda Ochola S, Kosura W. 2007. Case study on tobacco cultivation and possible alternative crops - Kenya. Available from: https:/www.who.int/tobacco/framework/cop/events/2007/ kenya_case_study.pdf (accessed: 22 April 2019).

32. Callard C. Follow the money: How the billions of dollars that flow from smokers in poor nations to companies in rich nations greatly exceed funding for global tobacco control and what might be done about it. Tob Control 2010; 19: 285-290.

33. Rowe M. 2019. Dossier: Tobacco's big child labour problem Geographical [Online]. Available from: http://geographical. co.uk/people/development/item/3172-dossier (accessed: 11 May 2019).

34. Otañez M, Glantz SA. Social responsibility in tobacco production? Tobacco companies use of green supply chains to obscure the real costs of tobacco farming. Tob Control 2011; 20: 403-411.

35. Fotedar S, Fotedar V. Green tobacco sickness: a brief review. Indian J Occup Environ Med 2017; 21: 101-104.

36. Joossens L, Raw M. Cigarette smuggling in Europe: who really benefits? Tob Control 1998; 7: 66-71.

37. Gilmore AB, McKee M. Moving East: how the transnational tobacco industry gained entry to the emerging markets of the former Soviet Union-part I: establishing cigarette imports. Tob Control 2004; 13: 143-150.

38. Gilmore AB, Gallagher AWA, Rowell A. Tobacco industry's elaborate attempts to control a global track and trace system and fundamentally undermine the Illicit Trade Protocol. Tob Control 2019; 28: 127-140.

39. Gilmore AB, Rowell A. 2018. The Tobacco industry's latest scam: How Big Tobacco is still facilitating tobacco smuggling, while also attempting to control a global system designed to prevent it. Available from: https://blogs.bmj.com/ tc/2018/06/19/the-tobacco-industrys-latest-scam-how-big-tobacco-is-still-facilitating-tobacco-smuggling-while-also-attempting-to-control-a-global-system-designed-to-prevent-it/ (accessed: 09 May 2019).

40. Haysom S. 2019. The illicit tobacco trade in Zimbabwe and South Africa: impacts and solutions. Available from: https://www.atlanticcouncil.org/images/publications/The_Illicit_Tobacco_Trade_ in_Zimbabwe_and_South_Africa.pdf (accessed: 11 May 2019).

41. WHO. 2018b. Fact sheet: Tobacco. Available from: https:// www.who.int/news-room/fact-sheets/detail/tobacco (accessed: 12 May 2019).

42. Novotny TE, Zhao F. Consumption and production waste: another externality of tobacco use. Tob Control 1999; 8: 75-80.

43. Ocean Conservancy. 2018 Cleanup Report: Building a Clean Swell. Available from: https://oceanconservancy.org/wp-content/uploads/2018/07/Building-A-Clean-Swell.pdf (accessed: 15 May 2019).

44. Slaughter E, Gersberg RM, Watanabe K, et al. Toxicity of cigarette butts, and their chemical components, to marine and freshwater fish. Tob Control 2011; 20 Suppl 1: i25-29. 
45. Lecours N, Almeida GE, Abdallah JM, Novotny TE. Environmental health impacts of tobacco farming: a review of the literature. Tob Control 2012; 21: 191-196.

46. WHO. n.d.-b. Tobacco Free Initiative: Environmental issues. Available from: https://www.who.int/tobacco/research/economics/rationale/environment/en/ (accessed: 11 May 2019).

47. Novotny TE, Hardin SN, Hovda LR, et al. Tobacco and cigarette butt consumption in humans and animals. Tob Control 2011; 20 Suppl 1: i17-20.

48. Green D. 2019. Cigarette butts are the forgotten plastic pollution - and they could be killing our plants. Available from: https://theconversation.com/cigarette-butts-are-the-forgotten-plastic-pollution-and-they-could-be-killing-our-plants119958?utm_medium=Social\&utm_source=Facebook\#Echobox=1563779504 (accessed: 23 May 2019).

49. Brathwaite R, Addo J, Smeeth L, Lock K. A systematic review of tobacco smoking prevalence and description of tobacco control strategies in Sub-Saharan African countries; 2007 to 2014. PLoS One 2015; 10: e0132401.

50. Ulucanlar S, Fooks GJ, Gilmore AB. The policy dystopia model: an interpretive analysis of tobacco industry political activity. PLoS Med 2016; 13: e1002125.

51. Savell E, Gilmore AB, Fooks G. How does the tobacco industry attempt to influence marketing regulations? A systematic review. PLoS One 2014; 9: e87389.

52. Smith KE, Savell E, Gilmore AB. What is known about tobacco industry efforts to influence tobacco tax? A systematic review of empirical studies. Tob Control 2013; 22: 144-153.

53. Brandt AM. Inventing conflicts of interest: a history of tobacco industry tactics. Am J Public Health 2012; 102: 63-71.

54. Oreskes N, Conway EM. Merchants of doubt: How a handful of scientists obscured the truth on issues from tobacco smoke to global warming. Bloomsbury Publishing, New York.

55. Campbell R, Balbach ED. Mobilising public opinion for the tobacco industry: the consumer tax alliance and excise taxes. Tob Control 2008; 17: 351-356.

56. Assunta M. 2017. Tobacco Industry Interference Index. ASEAN Report on Implementation of WHO Framework Convention on Tobacco Control Article 5.3. Available from: https:// seatca.org/dmdocuments/TI\%20Index\%202017\%209\%20 November\%20FINAL.pdf (accessed: 10 May 2019).

57. Mukherjee A, Ekanayake EM. Epistemic communities and the global alliance against tobacco marketing. Thunderbird Int Business Rev 2009; 51: 207-218.

58. Crosbie E, Sosa P, Glantz SA. Defending strong tobacco packaging and labelling regulations in Uruguay: transnational tobacco control network versus Philip Morris International. Tob Control 2018; 27: 185-194.

59. Crosbie E, Sosa P, Glantz SA. The importance of continued engagement during the implementation phase of tobacco control policies in a middle-income country: the case of Costa Rica. Tob Control 2017; 26: 60-68

60. Zatoński M. Poland's anti-tobacco advocacy - a historical outline. J Health Inequal 2016; 2: 26-31.

61. da Costa e Silva VL, Pantani D, Andreis M, et al. Bridging the gap between science and public health: taking advantage of tobacco control experience in Brazil to inform policies to counter risk factors for non-communicable diseases. Addiction 2013; 108: 1360-1366.

62. Uang R, Crosbie E, Glantz SA. Tobacco control law implementation in a middle-income country: Transnational tobacco control network overcoming tobacco industry opposition in Colombia. Glob Public Health 2018; 13: 1050-1064.

63. Graen L. 2018. Tobacco industry: Truly transformed or using SDGs as a smokescreen for old strategies? In: Köhrer E, Abshagen ML, Cavazzini A, Grün J, Maier J (eds.). Highjacking the SDGs? The Private Sector and the Sustainable Development Goals. Berlin: Brot für die Welt Evangelisches Werk für Diakonie und Entwicklung e.V., German NGO Forum on Environment and Development, Unfairtobacco, Global Policy Forum, Bischöfliches Hilfswerk MISEREOR.

64. Capewell S, Lloyd-Williams F. The role of the food industry in health: lessons from tobacco? Br Med Bull 2018; 125: 131-143.

65. Knai C, Petticrew M, Douglas N, et al. The public health responsibility deal: Using a systems-level analysis to understand the lack of impact on alcohol, food, physical activity, and workplace health sub-systems. Int J Environ Res Public Health 2018; 15: pii: E2895.

66. BAT. 2018. Transforming Tobacco: Sustainability Report 2018. Available from: https://www.bat.com/group/sites/UK_9D9KCY.nsf/vwPagesWebLive/DOAWWEKR/\$file/Sustainability_Report_2018.pdf (accessed: 11 May 2019).

67. Imperial Brands. 2018. Something better: Annual Report and Accounts 2018. Available from: https://www.imperialbrandsplc.com/content/dam/imperial-brands/corporate/investors/ annual-report-and-accounts/2018/pdfs/annual-report-2018. pdf (accessed: 22 May 2019).

68. JTI. 2018. JTI Group: Sustainability Report. Available from: https://www.jti.com/sites/default/files/jt-group-sustainability-report-fy-2018.pdf (accessed: 22 May 2019).

69. PMI. 2018. Sustainability Report 2018. Available from: https:// www.pmi.com/resources/docs/default-source/pmi-sustainability/pmi-sustainability-report-2018-low-res.pdf?sfvrsn=cada91b5_4 (accessed: 22 May 2019).

70. Drope J and contributors. 2019. Opinion: Tobacco companies will not bring about sustainable development. Available from: https:// www.devex.com/news/opinion-tobacco-companies-will-notbring-about-sustainable-development-94308 (accessed: 22 May 2019).

71. Lencucha R, Drope J, Labonte R. Rhetoric and the law, or the law of rhetoric: How countries oppose novel tobacco control measures at the World Trade Organization. Soc Sci Med 2016; 164: 100-107.

72. IPIP. 2017. TCCC urge ILO to break links with the tobacco industry and comply with the FCTC. Available from: https:// ipip.co.uk/tccc-urge-ilo-to-break-links-with-the-tobacco-industry-and-comply-with-the-fctc/ (accessed: 11 May 2019).

73. Framework Convention Alliance. 2019. Keep Tobacco Money Out of the ILO! Available from: https://www.fctc.org/wp-content/uploads/2019/06/ILO-Policy-Brief-final-20190628.pdf (accessed: 11 May 2019).

74. Berg CJ, Fong GT, Thrasher JF. The impact and relevance of tobacco control research in low-and middle-income countries globally and to the US. Addict Behav 2018; 87: 162-168. 
75. Hipple Walters B, Petrea I, Lando H. Tobacco control in lowand middle-income countries: changing the present to help the future. J Smoking Cessation 2018; 13: 187-188.

76. Namusisi Nyamurungi K, Achiri EN, Oginni A, et al. International collaboration to build tobacco control capacity: a case study of KOMPLY from the World Heart Federation Emerging Leaders program. Tobacco Induced Diseases 2018; 16: A628.

77. Black A, Santos Feijo R. 2018. Opinion: How tobacco control can boost sustainable development. Available from: https://www.devex.com/news/opinion-how-tobaccocontrol-can-boost-sustainable-development-93022 (accessed: 22 May 2019).

78. Lee S, Ling PM, Glantz SA. The vector of the tobacco epidemic: tobacco industry practices in low and middle-income countries. Cancer Causes Control 2012; 23 Suppl 1: 117-129.

79. Kohrman M, Quan G, Wennan L, Proctor RN (eds.). Stanford University Press, Poisonous Pandas, Redwood City 2018.

80. Neuburger MC. Balkan Smoke: Tobacco and the Making of Modern Bulgaria, Ithaca. Cornell University Press 2012

81. Szilágyi T, Chapman S. Tobacco industry efforts to erode tobacco advertising controls in Hungary. Cent Eur J Public Health 2004; 12: 190-196.

\section{AUTHORS' CONTRIBUTION}

BKM and MZ prepared the research concept and design, BKM and $M Z$ collected data, BKM and $M Z$ wrote the article, BKM revised the article, BKM and MZ finally approved it. 